\title{
ANALISIS PENGARUH STATUS GIZI DAN TABLET TAMBAH DARAH TERHADAP ANEMIA DALAM KEHAMILAN
}

\author{
Sumiyati \\ Program Studi Magister Ilmu Kebidanan, Pascasarjana Universitas Hasanuddin Makasar \\ sumiyatimalik2@gmail.com
}

\begin{abstract}
Anemia is a decrease in red blood cell levels (erythrocytes), which is a hemoglobin level less than $11 \mathrm{gr} / \mathrm{dl}$ in third trimester pregnant women. This study aims to determine the effect of nutritional status and distance of pregnancy on the occurrence of anemia in pregnancy. This study uses a cross sectional research design. Data collection was carried out by trained researchers and field workers including nutritional status, hemoglobin levels, consumption of Fe tablets for pregnant women. The subjects in this study were third trimester pregnant women with a total sample of 80 people taken using cluster sampling techniques and inclusion criteria. Data were analyzed using the chi-square statistical test. The results showed that there was one variable that significantly influenced the occurrence of anemia in pregnancy and there was one variable that did not significantly influence the occurrence of anemia in pregnancy. Statistical test results using the Chi-Square test obtained nutritional status $(p$-value $=0.929)$ and consumption of Fe tablets $(p$-value $=0.036)$
\end{abstract}

Keywords: Pregnant women, Anemia, Nutritional status, Fe tablets

\section{PENDAHULUAN}

Anemia dalam kehamilan didefinisikan sebagai suatu kondisi dimana ibu hamil memiliki kadar hemoglobin kurang dari $11,0 \mathrm{~g} / \mathrm{dl}$ pada trimester I dan III atau kadar hemoglobin kurang dari 10,5 g/dl pada trimester II (Evi, 2018; Eltayeb et al., 2018). Perbedaan tersebut berkaitan dengan terjadinya pengenceran darah (hemodilusi) selama kehamilan (Obaiet al., 2016).

Anemia merupakan salah satu kelainan darah yang umum terjadi ketika kadar sel darah merah (eritrosit) dalam tubuh menjadi terlalu rendah atau menurun sehingga kapasitas daya angkut oksigen untuk kebutuhan organ-organ vital pada ibu dan janin menjadi berkurang yang menyebabkan tingginya angka morbiditas dan mortalitas ibu (Anlaakuu \&Anto, 2017; Proverawati, 2011).

Faktor utama penyebab anemia adalah asupan zat besi yang kurang yang berasal dari asupan nutrisi ibu baik sebelum hamil maupun selama hamil. Sedangkan, determinan lainyang dapat mempengaruhi kejadian anemia adalah usia, tingkat pendidikan, status ekonomi, kunjungan antenatal care, kepatuhan komsumsi tablet $\mathrm{Fe}$ dan infeksi berbagai jenis
cacing(Hadi dkk., 2017; Arisman,2014; Hidayati \& Andyarini, 2018; Hadi, 2010).

Anemia dalam kehamilan dapat disebabkan status gizi yaitu kurangnya komsumsi makanan yang mengandung zat besi dan asam folat selama kehamilan. Salah satu masalah gizi yang banyak terjadi pada ibu hamil adalah anemia gizi yang merupakan masalah gizi mikro terbesar dan sulit diatasi di seluruh dunia. Hasil penelitian yang dilakukan oleh beberapa peneliti menyimpulkan bahwa terdapat hubungan yang signifikan antara status gizi terhadap kejadian anemia dalam kehamilan (Sab'ngatun \& Novitasari, 2018; Tadesse et al., 2017).

Menurut penelitian mengatakan bahwa masih tingginya kejadian anemia terjadi karena berbagai faktor diantaranya adalah komsumsi tablet Fe. Dimana masih ditemukan ibu yang tidak mengkomsusmi tablet $\mathrm{Fe}$ dengan berbagai macam alasan padahal pada masa kehamilan ibu memerlukan tambahan zat besi untuk meningkatkan jumlah sel darah merah serta membentuk sel darah merah janin dan plasenta. Ibu hamil yang jarang mengkomsumsi tablet $\mathrm{Fe}$ yang diberikan besar 
kemungkinan akan mengalami anemia jika tidak diimbangi oleh makanan yang mengadung zat besi (Sudikno \& Sandjaja, 2016).

Berdasarkan Data Dinas Kesehatan Kabupaten Polewali Mandar distribusi ibu hamil anemia pada tahun 2016 yaitu 2.546 $(23,1 \%)$ kasus dari 9.293 ibu hamil. Pada tahun 2017 ibu hamil anemia yaitu 2.605 (25,5 \%) kasus dari 9.272 ibu hamil. Sedangkan di tahun 2018 jumlah ibu hamil anemia yang dihitung mulai dari januari sampai september yaitu sebanyak 1.684 dengan jumlah ibu hamil 6.070. Angka kejadian anemia terbanyak terdapat pada puskesmas Pekkabata, Matakali, katumbangan dan campalagian. Berdasarkan hal tersebut maka penelitian ini bertujuan untuk mengetahui pengaruh status gizi dan tablet tambah darah $(\mathrm{Fe})$ anemia dalam kehamilan.

\section{METODE PENELITIAN \\ Jenis Penelitian}

Jenis penelitian yang digunakan adalah cross sectional.

\section{Lokasi Dan Waktu}

Penelitian akan dilaksanakan di Wilayah Kerja Puskesmas Pekkabata, Matakali, Katumbangan dan Campalagian di Kabupaten Polewali Mandar pada tanggal 29 Januari sampai dengan tanggal 15 April 2019.

\section{Populasi Dan Sampel}

Populasi dalam penelitian ini adalah seluruh ibu hamil trimester III di wilayah kerja Puskesmas Pekkabata, Matakali, Katumbangan dan Campalagian di Kabupaten Polewali Mandar dengan jumlah populasi sebanyak 94 ibu hamil Trimester III yang di ambil berdasarkan cluster random sampling.Sampel dalam penelitian ini adalah ibu hamil anemia trimester III yang berada di Wilayah Kerja Puskesmas Pekkabata, Matakali, Katumbangan dan Campalagian Kabupaten Polewali Mandar. Jumlah sampel dalam penelitian ini adalah 80 sampel.Tehnik pengambilan sampel yang digunakan adalah cluster sampling (Cluster Random Sampling).

\section{Pengumpulan Data}

Pengumpulan data dilakukan dengan menggunakan kuesioner berupa pertanyaanpertanyaa.Pengambilan data dilakukan secara serentak dalam satu waktu pada individu individu dari suatu populasi, tidak ada follow up serta untuk mencari hubungan antara variabel independen dan variabel dependen.

\section{Pengolahan dan Analisis Data}

Data dianalisis menggunakan analisis univariat dan bivariat. Analisis univariat dilakukan untuk melihat pengaruh status gizi dan tablet tambah darah Fe dalam kehamilan, Analisis bivariat dilakukan untuk menganalisis statistik Chi square dengan derajat kemaknaan atau tingkat signifikasi $(<\mathrm{a}=0,05)$. Dari uji korelasi Chi-square ditentukan harga koefisien korelasinya kemudian dihubungkan signifikan antara kedua variable.

\section{HASIL}

Nilai Median, Minimum dan Maksimum Berdasarkan Hasil Pemeriksaan HB

Tabel 4.1 merupakan tabel nilai median, minimum dan maksimum untuk mengetahui nilai terendah dan tertinggi dari kadar hemoglobin pada ibu hamil

\begin{tabular}{lc}
\hline & HB \\
\hline Median & $9,3 \mathrm{gr} / \mathrm{dl}$ \\
\hline Minimum & $6,4 \mathrm{gr} / \mathrm{dl}$ \\
\hline Maximum & $11,6 \mathrm{gr} / \mathrm{dl}$ \\
\hline
\end{tabular}

Sumber : uji statistik chi-square

Berdasarkan tabel 4.1 Diperoleh hasil nilai median kadar hempglobin yaitu 9,3 gr/dl, nilai minimum kadar hemoglobin yaitu 9,4 gr/dl, sedangkan nilai maksimum kadar hemoglobin yaitu 11,6 gr/dl. 


\section{Nilai Kuartil Berdasarkan Hasil Pemeriksaan HB}

Tabel 4.2 merupakan nilai kuartil dari hasil pemriksaan hemoglobin pada ibu hamil yang dibagi menjadi 4 bagian yang dihitung dengan menentukan median (nilai tengah).

\begin{tabular}{lcc}
\hline \multicolumn{3}{c}{ KUARTIL ANEMIA } \\
\hline U1 $(6,4-8,7 \mathrm{gr} / \mathrm{dl})$ & Jumlah $(\mathbf{n})$ & Persentase $(\%)$ \\
\hline Q2 $(>8,7-9,3 \mathrm{gr} / \mathrm{dl})$ & 20 & 25,0 \\
\hline Q3 $(>9,3-10,1 \mathrm{gr} / \mathrm{dl})$ & 18 & 28,8 \\
\hline Q4 $(>10,1-11,6 \mathrm{dr} / \mathrm{dl})$ & 19 & 22,5 \\
\hline Total & 80 & 23,8 \\
\hline
\end{tabular}

Sumber : uji statistik chi-square

Berdasarkan tabel 4.2 Diperolah hasil kuartil 1 (Q1) sebanyak 20 orang $(25,0 \%)$, kuartil 2 (Q2) sebanyak 23 orang $28,8 \%$, kuartil 3 (Q3) sebanyak 18 orang (22,5\%), kuartil 4 (Q4) sebanyak 19 orang $23,8 \%$ terdiri dari ibu hamil anemia dan tidak anemia

\section{Analisis Univariat}

Analisis univariat yang dilakukan bertujuan untuk mengetahui distribusi frekuensi dari masingmasing variabel yang diteliti yaitu umur, pendidikan, status ekonomi, kunjungan ANC, status gizi, paritas, jarak kehamilan, tablet Fe dan kecacingan.

Tabel 1. Distribusi Frekuensi Berdasarkan Karakteristik Sampel

\begin{tabular}{llcc}
\hline \multicolumn{2}{c}{ Variabel } & Jumlah $(\mathbf{n})$ & Persentase (\%) \\
\hline \multirow{2}{*}{ Status Gizi (LILA) } & $<23,5 \mathrm{~cm}$ & 7 & 8,8 \\
\multirow{2}{*}{ Komkumsi Tablet Fe } & $\geq 23,5 \mathrm{~cm}$ & 73 & 91,3 \\
\multirow{4}{*}{ Kejadian anemia } & $<90$ tablet & 63 & 78,8 \\
& $\geq 90$ tablet & 17 & 21,3 \\
& Anemia & 75 & 93,8 \\
& Tidak anemia & 5 & 6,3 \\
\hline
\end{tabular}

Tabel 1 menunjukkan distribusi frekuensi berdasarkan karateristik Status Gizi (LILA)Menunjukkan bahwa dari 80 responden (100\%), jumlah ibu hamil dengan status gizi (LILA) $<23,5 \mathrm{~cm}$ sebanyak 7 orang $(8,8 \%)$ sedangkan jumlah ibu hamil dengan kategori status gizi (LILA) $\geq 23,5 \mathrm{~cm}$ sebanyak 73 orang $(91,3 \%)$

Distribusi frekuensi berdasarkan karateristik komsumsi tablet tambah darah (Fe) Menunjukkan bahwa dari 80 responden $(100 \%)$, mayoritas responden tidak patuh dalam mengkomsumsi tablet tambah darah yaitu kurang dari 90 tablet sebanyak 63 (78,8\%). Sedangkan jumlah responden dengan kategori patuh dalam mengkomsumsi tablet tambah darah yaitu lebih atau sama dengan 90 tablet sebanyak 17 orang $(21,3 \%)$.

Distribusi frekuensi kejadian berdasarkan kategorianemiaMenunjukkan bahwa dari 80 responden (100\%), mayoritas responden ibu hamil trimester III mengalami kejadian anemia dengan jumlah 75 orang (93,8\%), sedangkan ibu hamil trimester III yang tidak mengalami anemia sebanyak 5 orang $(6,3 \%)$. 
Tabel 2. Hubungan Pengaruh Status Gizi dan Tablet Tambah Darah (Fe) Terhadap Anemia Dalam Kehamilan

\begin{tabular}{|c|c|c|c|c|c|c|c|c|c|c|c|c|}
\hline \multirow{2}{*}{\multicolumn{2}{|c|}{ Variabel }} & \multicolumn{2}{|c|}{ Q1 } & \multicolumn{2}{|c|}{ Q2 } & \multicolumn{2}{|c|}{ Q3 } & \multicolumn{2}{|c|}{ Q4 } & \multicolumn{2}{|c|}{ Total } & \multirow{2}{*}{$\begin{array}{c}\text { P- } \\
\text { Value }\end{array}$} \\
\hline & & $\mathbf{n}$ & $\%$ & $\mathbf{n}$ & $\%$ & $\mathbf{n}$ & $\%$ & n & $\%$ & $\mathbf{n}$ & $\%$ & \\
\hline Status & $<$ & & & & & & & & & & & \\
\hline \multirow[t]{2}{*}{ Gizi } & 23,5 & 2 & $28,6 \%$ & 2 & $28,6 \%$ & 2 & $28,6 \%$ & 1 & $14,3 \%$ & 7 & $100,0 \%$ & \multirow[b]{2}{*}{0,929} \\
\hline & $\begin{array}{l}\mathrm{cm} \\
\geq 23,5 \\
\mathrm{~cm}\end{array}$ & 18 & $24,7 \%$ & 21 & $28,8 \%$ & 16 & $21,9 \%$ & 18 & $24,7 \%$ & 73 & $100,0 \%$ & \\
\hline \multirow[t]{2}{*}{$\begin{array}{l}\text { Komsumsi } \\
\text { Tablet Fe }\end{array}$} & $\begin{array}{l}<90 \\
\text { Tablet }\end{array}$ & 19 & $30,2 \%$ & 15 & $23,8 \%$ & 12 & $19,0 \%$ & 17 & $27,0 \%$ & 63 & $100,0 \%$ & \multirow[b]{2}{*}{0,036} \\
\hline & $\begin{array}{l}\geq 90 \\
\text { Tablet }\end{array}$ & 1 & $5,9 \%$ & 8 & $47,1 \%$ & 6 & $35,3 \%$ & 2 & $11,8 \%$ & 17 & $100,0 \%$ & \\
\hline
\end{tabular}

Sumber : Uji Chi-Square

Berdasarkan hasil analisis hubungan antara status gizi dengan kejadian anemia dalam kehamilan pada ibu hamil trimester III diperoleh hasil 7 orang ibu hamil dengan status gizi kurang (LILA $<23,5 \mathrm{~cm}$ ), terdapat 2 orang $(28,6 \%)$ ibu hamil dengan kejadian anemia kuartil tingkat 1 (Q1), 2 orang $(28,6 \%)$ ibu hamil dengan kejadian anemia kuartil tingkat 2 (Q2), 2 orang $(28,6 \%)$ ibu hamil dengan kejadian anemia kuartil tingkat 3 (Q3) dan 1 orang $(14,3 \%)$ dengan kejadian anemia kuartil tingkat 4 (Q4). Sedangkan jumlah ibu hamil dengan status gizi baik/normal (LILA $\geq 23,5 \mathrm{~cm}$ ) sebanyak 73 orang, terdapat 18 orang $(24,7 \%)$ ibu hamil dengan kejadian anemia kuartil tingkat 1 (Q1), 21 orang $(28,8 \%)$ ibu hamil dengan kejadian anemia kuartil tingkat 2 (Q2), 16 orang (21,9\%) ibu hamil dengan kejadian anemia kuartil tingkat 3 (Q3) dan 18 orang $(24,7 \%)$ dengan kejadian anemia kuartil tingkat 4 (Q4).

Berdasarkan hasil analisis hubungan antara komsumsi tablet $\mathrm{Fe}$ dengan kejadian anemia dalam kehamilan pada ibu hamil trimester III diperoleh hasil 63 orang ibu hamil yang mengkomsumsi tablet Fe $<90$ tablet, terdapat 19 orang $(30,2 \%)$ ibu hamil dengan kejadian anemia kuartil tingkat 1 (Q1), 15 orang $(23,8 \%)$ ibu hamil dengan kejadian anemia kuartil tingkat 2 (Q2), 12 orang $(19,0 \%)$ ibu hamil dengan kejadian anemia kuartil tingkat $3(\mathrm{Q} 3)$ dan 17 orang $(27,0 \%)$ dengan kejadian anemia kuartil tingkat 4 (Q4). Sedangkan jumlah ibu hamil yang mengkomsumsi tablet $\mathrm{Fe} \geq 90$ tablet sebanyak 17 orang, terdapat 1 orang $(5,9 \%)$ ibu hamil dengan kejadian anemia kuartil tingkat 1 (Q1), 8 orang $(47,1 \%)$ ibu hamil dengan kejadian anemia kuartil tingkat 2 (Q2), 6 orang $(35,3 \%)$ ibu hamil dengan kejadian anemia kuartil tingkat $3(\mathrm{Q} 3)$ dan 2 orang $(11,8 \%)$ dengan kejadian anemia kuartil tingkat $4(\mathrm{Q} 4)$.

Berdasarkan hasil analisis hubungan antara infeksi cacing dengan kejadian anemia dalam kehamilan pada ibu hamil trimester III diperoleh hasil 14 orang ibu hamil yang mengalami positif kecacingan, terdapat 4 orang $(28,6 \%)$ ibu hamil dengan kejadian anemia kuartil tingkat 1 (Q1), 5 orang $(35,7 \%)$ ibu hamil dengan kejadian anemia kuartil tingkat 2 (Q2), 2 orang (14,3\%) ibu hamil dengan kejadian anemia kuartil tingkat $3(\mathrm{Q} 3)$ dan 3 orang $(21,4 \%)$ dengan kejadian anemia kuartil tingkat $4(\mathrm{Q} 4)$. Sedangkan jumlah ibu hamil yang tidak mengalami kecacingan atau negatif sebanyak 66 orang, terdapat 16 orang $(24,3 \%)$ ibu hamil dengan kejadian anemia kuartil tingkat 1 (Q1), 18 orang $(27,3 \%)$ ibu hamil dengan kejadian anemia kuartil tingkat 2 (Q2), 16 orang $(24,2 \%)$ ibu hamil dengan kejadian anemia kuartil tingkat 3 (Q3) dan 16 orang $(24,2 \%)$ dengan kejadian anemia kuartil tingkat $4(\mathrm{Q} 4)$. 


\section{PEMBAHASAN}

Dalam penelitian ini mayoritas ibu hamil memiliki status gizi normal dimana untuk mengetahui status gizi ibu hamil antara lain dengan mengukur lingkar lengan atas (LILA). Dikatakan status gizi normal apabila lingkar lengan atas $\geq 23,5 \mathrm{~cm}$ dan status gizi tidak normal (KEK), yaitu $<23,5 \mathrm{~cm}$ (Waryana, 2010). Menurut teori bahwa anemia pada ibu hamil adalah karena jarak kelahiran yang pendek hal ini disebabkan oleh kekurangan nutrisi yang merupakan mekanisme biologis dan memulihkan faktor hormonal. Jarak kehamilan juga sangat berpengaruh terhadap kejadian anemia pada saat kehamilan yang berulang dalam waktu singkat akan mengurangi cadangan zat besi ibu (Amiruddin \& Wahyuddin, 2014).

Pada hasil penelitian ini ibu hamil dengan status gizi rendah (KEK) terbukti mengalalami kejadian anemia.Kehamilan selalu berhubungan dengan perubahan fisiologis yang berakibat peningkatan volume cairan dan sel darah merah serta penurunan konsentrasi protein pengikat gizi dalam sirkulasi darah, begitu juga dengan penurunan gizi mikro. Masa kehamilan merupakan masa pertumbuhan dan perkembangan janin menuju masa kelahiran sehingga gangguan gizi yang terjadi pada masa kehamilan akan berdampak besar bagi kesehatan ibu dan janin. Oleh karenanya status KEK pada ibu hamil dapat berdampak pada kejadian anemia ibu hamil juga pada kejadian BBLR dan stunting (Dekker, et al. 2010).

Dalam penelitian ini mayoritas ibu hamil memiliki status gizi normal dimana untuk mengetahui status gizi ibu hamil antara lain dengan mengukur lingkar lengan atas (LILA). Dikatakan status gizi normal apabila lingkar lengan atas $\geq 23,5 \mathrm{~cm}$ dan status gizi tidak normal (KEK), yaitu $<23,5 \mathrm{~cm}$ (Waryana.2010). Dalam penelitian ini ibu hamil dengan kondisi status gizi baik atau tidak KEK nyatanya masih saja mengalami kejadian anemia. Hal tersebut juga disebabkan apabila ibu hamil status gizinya baik maka kemungkinan masih dapat mengalami anemia, sebab terdapat faktor lain yang dapat mempengaruhi terjadinya anemia.

Hasil penelitian ini didukung oleh hasil penelitian yang telah dilakukan oleh nurdina takdir (2017) yang menyatakan bahwa tidak ada hubungan yang bermakna antara status gizi dengan kejadian anemia pada ibu hamil trimester III, diperoleh nilaip $\mathrm{p}$-value $=0,177$ (p-value $>0,05$ )

Hasil penelitian selanjutnya adalah hasil penelitian Nurhidayati (2015) didapatkan hasil uji statistik p-value $=0,189$ menyatakan bahwa tidak ada hubungan antara status gizi dengan kejadian anemia pada ibu hamil trimester III. Kondisi ini disebabkan oleh apabila ibu hamil dengan status gizi baik maka kemungkinan masih dapat mengalami anemia.

KEK erat kaitannya dengan kejadian anemia karena berkaitan dengan kekurangan asupan protein yang dikomsumsi oleh ibu hamil yang bersifat kronis atau terjadi dalam jangka waktu yang lama. Dengan demikian kurangnya asupan protein akan berdampak pada terganggunya penyerapan zat besi yang berakibat pada terjadinya defesiensi besi (Jurnal kesehatan kartika)

Status gizi merupakan hasil akhir dari keseimbangan antara makanan yang dikomsumsi dengan kebutuhan tubuh.Status gizi wanita merupakan salah satu faktor yang harus diperhatikan karena rendahnya status gizi dapat menyebabkan anemia yang mengakibatkan kualitas fisik yang rendah dan berpengaruh pada efisiensi reproduksi.Semakin tinggi asupan gizi seseorang maka semakin baik pula kondisi fisiknya, sehingga secara tidak langsung mempengaruhi efisiensi reproduksi.

Rendahnya pendidikan ibu mempengaruhi penerimaan informasi sehingga pengetahuan tentang zat besi $(\mathrm{Fe})$ menjadi terbatas. Menurut peneliti, semakin tinggi tingkat pendidikan seseorang, semakin mudah menerima informasi sehingga semakin banyak pula pengetahuan yang dimiliki baik dalam pencegahan anemia kehamilan, pemenuhan kebutuhan gizi ibu hamil, dan pemanfaatan pelayanan kesehatan yang ada. Sebaliknya pendidikan yang rendah akan menghambat perkembangan sikap seseorang dalam penerimaan informasi, hal tersebut menyebabkan ibu tidak mengetahui tentang kebutuhan zat besi ibu hamil dan tidak memanfaatkan pelayanan kesehatan yang tersedia. Kurangnya informasi tersebut menghambat perubahan pola hidup sehat, mereka lebih memilih saran dari nenek moyang yang dianggap lebih baik dan mengabaikan saran dari petugas kesehatan. 
Salah satu contohnya yaitu ibu hamil tidak dianjurkan minum susu karena akan menyebabkan bayi besar. Demikian halnya dengan ibu yang berpendidikan tinggi akan memeriksakan kehamilannya secara teratur demi menjaga keadaan kesehatan dirinya dan anak dalam kandungannya(Walyani,2018).

Tablet $\mathrm{Fe}$ adalah garam besi dalam bentuk tablet atau kapsul yang apabila dikonsumsi secara teratur dapat meningkatkan jumlah sel darah merah. Wanita hamil mengalami pengeceran sel darah merah sehingga memerlukan tambahan zat besi untuk meningkatkan jumlah sel darah merah dan untuk sel darah janin.Zat besi (Fe) merupakan microelement yang esensial bagi tubuh.Zat ini terutama diperlukan dalam hemopobesis (pembentukan darah,) yaitu dalam sintesa hemoglobin $(\mathrm{Hb})$ terutama ibu hamil yang kebutuhan zat besi meningkat. Didalam tubuh sebagian besar $\mathrm{Fe}$ dapat terkonjugasi dengan protein dalam bentuk ferro atau ferri.Sejalan dengan hasil penelitian yang dilakukan oleh Wawointana (2013),

Penelitian ini sejalan dengan penelitian yang dilakukan oleh Rohmah (2014), Hasil pengujian hubungan kecukupan konsumsi tablet fe dengan kejadian anemia diperoleh nilai $\chi 2$ hit sebesar 4,059 dengan $\mathrm{p}$-value $=$ 0,044. Kesimpulan uji adalah H0 ditolak, sehingga dapat disimpulkan ada hubungan yang bermakna kecukupan konsumsi tablet fe dengan kejadian anemia pada ibu hamil di Wilayah kerja Puskesmas Tawangsari Sukoharjo.

Dalam penelitian ini ibu hamil yang patuh dalam mengkonsumsi tablet Fe banyak yang mengalami anemia kehamilan, hal ini disebabkan karena ibu hamil yang patuh mengkonsumsi tablet $\mathrm{Fe}$ namun tidak memperhatikan faktor lain yang dapat menyebabkan anemia dalam kehamilan, misalnya ibu hamil tersebut mengkomsumsi tablet $\mathrm{Fe}$ namun sering mengkomsumsi minuman kopi dan teh. Dalam penelitian ini terdapat ibu hamil yang tidak bisa minum tablet $\mathrm{Fe}$ jika tidak dibarengi dengan minum air teh. Sedangkan menurut teori makanan atau minuman yang dikonsumsi ibu dapat mengganggu penyerapan zat besi dalam tubuh, seperti ibu menkonsumsi kopi, teh dan susu dimana kandunganya yang terdiri dari tannin, fitat, oksalat, kalsium akan mengikat besi sebelum diserap oleh mukosa usus, sehingga akan mengurangi penyerapan zat besi dalam tubuh. Dengan berkurangnya penyerapan zat besi dalam tubuh maka jumlah feritin juga akan berkurang yang mengakibatkan terjadinya kurangnya kadar hemoglobin dalam darah yang disebut dengan kejadian anemia. Berdasarkan data yang ditemukan di lapangan, yang paling sering dilakukan ibu dalam mengkonsumsi tablet besi pada pagi hari adalah menggunakan air teh, karena dianggap menggurangi efek mual dan muntah. Jika ibu mengkonsumsi tablet besi malam hari dimana kondisi lambung dalam keadaan kosong dan pada saat tidur sistem metabolisme tubuh bekerja dengan baik sehingga mempercepat penyerapan zat besi dalam tubuh.

Dalam penelitian ini ditemukan bahwa proporsi ibu hamil yang tidak patuh dalam mengkonsumsi tablet $\mathrm{Fe}$ sangat tinggi dan mengalami anemia yaitu sekitar 93,7\% dan sebaliknya ibu hamil yang dikategorikan patuh dalam konsumsi tablet $\mathrm{Fe}$ dan mengalami anemia kehamilan hanya $94,1 \%$. Hal ini menunjukkan bahwa kepatuhan ibu hamil dalam mengkonsumsi tablet $\mathrm{Fe}$ sangat berpengaruh terhadap kejadian anemia pada ibu hamil. Perilaku ibu hamil yang tidak patuh bisa disebabkan kurangnya pengetahuan mengenai fungsi dari tablet Fe. Sebagian besar responden yang tidak patuh dalam mengkonsumsi tablet Fe adalah terkait waktu meminum tablet $\mathrm{Fe}$, sebagian responden meminum tablet Fe dipagi hari namun secara teori waktu yang tepat dalam mengkonsumsi tablet $\mathrm{Fe}$ adalah malam hari. Jika ibu mengkonsumsi tablet besi pada pagi atau siang hari penyerapan zat besi tidak maksimal, hal ini dipengaruhi oleh faktor. Selain itu juga ibu hamil tidak rutin mengkomsumsi tablet $\mathrm{Fe}$ dikarenakan bau dan rasa tablet Fe yang tidak enak dileher pada saat diminum yang menyebabkan mual bahkan muntah jika dikomsumsi. Selain itu ada juga ibu hamil yang mengatakan bahwa jika mengkomsumsi tablet Fe makan dapat membuat tekanan darah menjadi tinggi (hipertensi) serta ibu hamil dalam penelitian ini ada beberapa yang mengalami positif kecacingan.

Dalam buku Tarwono (2007) mengatakan bahwa pemberian tablet $\mathrm{Fe}$ selama kehamilan merupakan salah satu cara yang dianggap paling cocok bagi ibu hamil untuk meningkatkan kadar hemoglobin. Kemudian Kementrian kesehatan RI juga telah membuat rencana strategi pembangunan kesehatan salah satunya adalah target cakupan 
pemberian tablet Fe pada ibu hamil pada tahun 2015-2019. Meskipun program pemerintah dalam upaya penanggulangan anemia pada ibu hamil dengan pemberian tablet Fe sebanyak 90 tablet selama kehamilan telah berjalan, namun kejadian anemia pada ibu hamil masih tetap terjadi. Hal ini diakibatkan oleh berbagai faktor diantaranya kurangnya asupan zat besi dari makanan, perdarahan serta kurangnya komsumsi tablet Fe.

Ibu hamil perlu mengkonsumsi tablet Fe selama kehamilan, karena kebutuhan zat besi ibu hamil meningkat selama kehamilan. Tablet Fe adalah garam besi dalam bentuk tablet atau kapsul yang apabila dikonsumsi secara teratur dapat meningkatkan jumlah sel darah merah. Wanita hamil mengalami pengeceran sel darah merah sehingga memerlukan tambahan zat besi untuk meningkatkan jumlah sel darah merah dan untuk sel darah janin. Zat besi (Fe) merupakan microelement yang esensial bagi tubuh. Zat ini terutama diperlukan dalam hemopobesis (pembentukan darah,) yaitu dalam sintesa hemoglobin $(\mathrm{Hb})$ terutama ibu hamil yang kebutuhan zat besi meningkat.

Hasil penelitian ini sejalan dengan hasil penelitian yang dilakukan oleh Arifdkk (2015), penelitian tersebut merupakan penelitian survei analitik dengan rancangan cross sectional study dengan jumlah sampel 72 yang menjelaskan bahwa tidak terdapat hubungan antara infeksi cacing dengan kadar hemoglobin pada ibu hamil dengan nilai $(\mathrm{p}=0,144>0,05)$ di kabupaten Bolaang Monngondow Utara.

\section{KESIMPULAN DAN SARAN}

Berdasarkan hasil dan pembahasan maka dapat disimpulkan bahwa terdapat satu variabel yang berpengaruh secara signifikan terhadap terjadinya anemia dalam kehamilan terhadap anemia dalam kehamilan yaitu komsumsi tablet $\mathrm{Fe}$ dan Terdapat variabel lainnya yang tidak berpengaruh secara signifikan terhadap terjadinya anemia dalam kehamilan yaitu status gizi. Di sarankan untuk di adakan pemeriksaan kecacingan di setiap masing-masing puskesmas untuk mengetahui salah penyebab anemia dalam kehamilan.

\section{DAFTAR PUSTAKA}

Amiruddin \& Wahyuddin.(2014). 'Studi Kasus Kontrol Faktor Biomedis Terhadap
Kejadian Anemia Ibu Hamil di Puskesmas Bantimurung Maros, Jurnal Medika Nusantara. Vol. 25 No. 2.', medika nusantara, 2(2), p. 110.

Anlaakuu P. \& Anto, F. (2017). 'Anaemia in pregnancy and associated factors: a cross sectional study of antenatal attendants at the Sunyani Municipal Hospital, Ghana',BMC research notes. BioMed Central, 10(1), p. 402. doi: 10.1186/s13104-017-2742-2.

Antono \&Dwi S. (2017). 'Hubungan Frekuensi Anemia Cara Dengan Kejadian Anemia Pada Ibu Hamil Trimester', 6(1), pp. 32-38.

Arif Y., Damajanty,\& Joice.(2015). 'Hubungan Infeksi Cacing dengan TNF dan Kadar Hemoglobin pada ibu hamil', Jurnal e-Biomedik (eBm), 3(1).

Arisman M. (2014).Gizi dalam Daur Kehidupan. Jakarta: Buku Kedokteran EGC.

Astriana W. (2017). 'Kejadian Anemia pada Ibu Hamil Ditinjau dari Paritas dan Usia', Jurnal Aisyah: Jurnal Ilmu Kesehatan, 25(2), p. 123. doi: 10.30604/jika.v2i2.57.

Citrakesumasari. (2012).Anemia Gizi Masalah Dan Pencegahannya. Yogyakarta: Kalika.

Crowther K.T.S., Emmanuel,\& Williams. (2017). 'Parasitic infection and maternal anaemia among expectant mothers in the Dangme East Distric of Ghana', Journal of Tay et al. BMC Res Notes. doi: 10.1186/s13104-0162327-5.

Eltayeb R. et al. (2018). 'The prevalence of serum magnesium and iron deficiency anaemia among Sudanese women in early pregnancy: a cross-sectional study', Transactions of The Royal Society of Tropical Medicine and Hygiene, pp. 1-5. doi: 10.1093/trstmh/try109.

Evi P. (2018). Evidence-Based Dalam Kebidanan Kehamilan, Persalinan dan Nifas. 1st edn. Edited by I. sari Pamilih Eko Karyuni. Jakarta: EGC. Hal. 76 - 97

Hadi A., Marfina M. \& Iskandar I. (2017). 'Efikasi Suplementasi Tablet Besi, Vitamin C, Penyuluhan dan Pendampingan Terhadap Kadar 
Hemoglobin Ibu Hamil', AcTion: Aceh Nutrition Journal, 2(2), p. 91. doi: 10.30867/action.v2i2.60.

Hadi H. (2010).Meningkatkan kepatuhan minum tablet besi ibu hamil: Pentingnya peran suami. Berita kedokteran masyarakat.

Hidayati I. \& Andyarini E. N. (2018). 'Hubungan Jumlah Paritas dan Umur Kehamilan dengan Kejadian Anemia Ibu Hamil', 2(April), pp. 42-47.

Kuspriyanto \& Susilowati. (2016).Gizi Dalam Daur Kehidupan. Bandung: Refika Meditama. Hal. 15-18

Manuaba. (2010).Ilmu Kebidanan Penyakit Kandungan dan KB. Jakarta: EGC.

Mulgeta M., Zelalem A.\& Meseret A. B. E. (2013). 'Prevalence and predictors of maternal anemia during pregnancy in Gondar, north west Ethiopia. Hindawi Publish Corp. 2013;2014:2-3.', 2014.

Obai G., Odongo P. \& Wanyama R. (2016).

'Prevalence of anaemia and associated risk factors among pregnant women attending antenatal care in Gulu and Hoima Regional Hospitals in Uganda: A cross sectional study', BMC Pregnancy and Childbirth. BMC Pregnancy and Childbirth, 16(1), pp. 1-7. doi: 10.1186/s12884-016-0865-4.

Proverawati A. (2011). Anemia dan Anemia Kehamilan. Yogyakarta: Nuha Medika. Hal. 14 - 16

Retno P. D. \& Pratiwi B. R. (2017).Prosiding Seminar Nasional Kebidanan Dan Presentasi Hasil Riset Membangun Jiwa Sociopreneurship Berwawasan Internasional Di DuniaKesehatan. Mataram.

Sab'ngatun \& Novitasari A. (2018). 'The Relationship Between Nutritional Status And Hemoglobin Levels In The Third Trimester Pregnant Women', Avicenna Journal of Health Research, $1(1)$, pp. 55-64.

Saminem. (2008).Resiko komplikasi kehamilan. Jakarta. Hal. 1-6

Sudikno \& Sandjaja. (2016). 'Prevalensi dan faktor resiko anemia pada wanita usia subur di rumah tangga miskin di kabupaten tasikmalaya dan ciamis, provinsi jawa barat', Jurnal kesehatan reproduksi, 7(2).

Stephen G. et al. (2018). Anemia in Pregnancy: Prevalence, Risk Factors, and Adverse Perinatal Outcomes in Northen Tanzania. Volume 2018. Doi : 10.1155/2018/1846280, ISSN : 20901275

Tadesse S. E. et al. (2017). 'Determinants of anemia among pregnant mothers attending antenatal care in Dessie town health facilities, northern central Ethiopia, unmatched case -control study', PLoS ONE, 12(3), pp. 1-9. doi: 10.1371/journal.pone.0173173.

Walyani E. S. (2018).Asuhan Kebidanan Pada Kehamilan. Yogyakarta: PRESS, PUSTAKA BARU.

Weldekidan F. et al. (2018). 'Determinants of Anemia among Pregnant Women Attending Antenatal Clinic in Public Health Facilities at Durame Town: Unmatched Case Control Study', 2018. doi: $10.1155 / 2018 / 8938307$.

Wungkana. (2016). 'Hubungan Antara Frekuensi Antenatal Care dengan Kajdian Anemia pada ibu hamil di Puskesmas Bahu Kota Manado. Fakultas Kesehatan Masyarakat, Universitas Ratulangi Manado', jurnal IKMAS, 8(3).

Waryana. (2010). Gizi Reproduksi. Yogyakarta. Pustaka Rihama 